\title{
The relationship between serum hormone levels (follicle-stimulating hormone, luteinizing hormone, total testosterone) and semen parameters
}

\author{
Mehmet Zeynel Keskin ${ }^{1}$, Salih Budak ${ }^{1}$, Tuğba Zeyrek ${ }^{2}$, Orçun Çelik ${ }^{1}$, Oguz Mertoglu ${ }^{1}$, \\ Mehmet Yoldas ${ }^{1}$, Yusuf Özlem İlbey ${ }^{1}$ \\ ${ }^{1}$ Tepecik Research and Education Hospital, Clinic of Urology, Izmir, Turkey; \\ ${ }^{2}$ Tepecik Research and Education Hospital, Assisted Reproductive Techniques Department, Clinic of Embryology, Izmir, Turkey.
}

\begin{abstract}
Summary Objective: The aim of this study was to investigate the effect of serum

gonadotropin and total testosterone levels on semen parameters.

Materials and Methods: Three hundred and eighty-two patients that applied to a male infertility polyclinic were included in our study. Serum gonadotropin and total testosterone levels and semen parameters of the patients were analyzed during the first visit to the clinic. The reference FSH value was 1.5-12.4 $\mathrm{mIU} / \mathrm{mL}$, that of $\mathrm{LH}$ was 1.7-8.6 $\mathrm{mIU} / \mathrm{mL}$ and the reference value for total testosterone was 249-836 $\mathrm{ng} / \mathrm{dL}$.

Results: While there was no statistically significant difference between the patients with low gonadotropin levels and the controls regarding any of the semen parameters ( $p>$ 0.05 ), there was a strong statistically significant difference between the patients with high gonadotropin levels and the controls regarding sperm concentration $(p=0.000)$, total motility $(p=0.000)$, progressive motility $(p=0.000)$, and morphology $(p=0.000)$. There was a strong statistically significant difference between the patients with low testosterone levels and the controls regarding total motility $(p=0.012)$ and progressive motility $(p=0.010)$, and a weak statistically significant difference in morphology $(p=0.042)$. There was no statistically significant difference in semen volume or sperm concentration $(p>0.05)$. There was no statistically significant difference in any of the semen parameters between the patients with high testosterone levels and the controls $(p>0.05)$.

Conclusions: Our findings especially regarding $L H$ and $T$ levels are not in agreement with previous reports. In this regard, there is a need for larger-scale and randomized trials to resolve this discrepancy.
\end{abstract}

KEY WORDS: Gonadotropin; Semen; Testosterone.

Submitted 5 January 2015; Accepted 31 March 2015

\section{INTRODUCTION}

The subfertility rate in couples of worldwide is 15\% (1). Evaluation of spermatogenesis has an important role in diagnosis, and semen analysis is usually the initial test performed. If an abnormality is determined in patients after semen analysis, hormone levels may then be measured to determine the cause of subfertility. Subfertility may be due to testicular obstruction (2) or abnormal hormone levels, leading to dysregulated sperm production.

Follicle-stimulating hormone (FSH), luteinizing hormone ( $\mathrm{LH}$ ), and testosterone ( $\mathrm{T}$ ) are key hormones in fertility health. FSH and LH are types of 'gonadotropins' that are synthetized in the adenohypophysis of vertebrates due to the effect of gonadotropin-releasing hormone $(\mathrm{GnRH})$. Production of gonadotropins is controlled by $T$, estradiol (E2), and inhibin B $(3,4)$.

$\mathrm{LH}$ binds to receptors on Leydig cells, leading to increased release of intratesticular T. FSH binds directly to Sertoli cells, leading to secretion of many factors crucial for sperm development. As Leydig cells, Sertoli cells, and peritubular cells in the seminiferous tubules are important in spermatogenesis (5), the decrease in FSH and LH production results in reduced testicular function, and infertility.

FSH and inhibin B are considered markers of spermatogenesis and Sertoli cell function (6-10). In previous studies, a negative correlation was found between FSH levels and sperm concentration, while a positive correlation was found between inhibin B levels and sperm concentration (10-12). No relationship between semen parameters and LH and T levels was detected (10). The aim of this study was to investigate the relationship between semen parameters and serum gonadotropin and total $\mathrm{T}$ levels.

\section{MateriaLS AND METHODS}

Three hundred and eighty-two patients from the outpatient clinics of urology for male infertility problems at the Ege Maternity Hospital between August 2014 and December 2014 were included in the study. Initially, history was taken and a physical examination carried out. Patients who had a characteristic that could affect semen parameters (drug, hypovolemic testis, varicocele, systemic diseases etc.) were excluded from the study. Semen analysis and serum hormone levels were evaluated in the remaining patients. Blood samples for determination of hormone levels were collected before 10:00 am. Hormone analysis was performed with a Roche Cobas and 601 HITACHI device by microparticle enzyme immunoassay. 
Reference values for FSH levels were 1.5 to $12.4 \mathrm{mIU} / \mathrm{mL}$, those of $\mathrm{LH}$ were 1.7 to 8.6 $\mathrm{mIU} / \mathrm{mL}$, and reference values of total $\mathrm{T}$ were 249 to $836 \mathrm{ng} / \mathrm{dL}$.

Semen samples were taken on the same day by manual masturbation, following the patient refraining from sex for 3-6 days. Samples were evaluated by the same embryologist in the Assisted Reproduction Treatment Center Spermiogram Laboratory of the hospital. Semen samples were assessed according to the WHO 2010 criteria (13). The relationship between serum FSH, LH, total T levels and semen parameters was investigated using the IBM Statistical Package for the Social Sciences (SPSS) version 22.0 software. A value of $\mathrm{p}<0.05$ was taken to indicate statistical significance.

\section{RESULTS}

Upon analysis of semen parameters and hormone levels of the 382 patients included in the study, the mean FSH level was $7.91 \mathrm{mIU} / \mathrm{mL}$ and the mean $\mathrm{LH}$ level was $6.26 \mathrm{mIU} / \mathrm{mL}$. The mean $\mathrm{T}$ level was $425.21 \mathrm{ng} / \mathrm{dL}$, semen volume was 2.86 $\mathrm{mL}$, sperm concentration was $26.4 \times$ $10 \% / \mathrm{mL}$, total motility $42 \%$, progressive motility 29\%, and morphology was found to be $2 \%$ (Table 1)

Patients were divided into three groups according to FSH, LH, and $\mathrm{T}$ levels. Patients with a FSH level of 0-1.5 mIU $\mathrm{mL}$ were considered Group 1 (low) ( $\mathrm{n}=$ 9), patients with a FSH level of 1.5-12.4 $\mathrm{mIU} / \mathrm{mL}$ were considered Group 2 (normal) $(\mathrm{n}=320)$ ), and those with a FSH level > $12.4 \mathrm{mIU} / \mathrm{mL}$ were considered Group 3 (high) $(\mathrm{n}=53)$. Patients with a LH level of 0-1.7 mIU/mL were considered Group 1 (low) $(n=4)$, patients with a LH level of 1.7-8.6 mIU/mL were considered Group 2 (normal) $(\mathrm{n}=321)$, and those with a $\mathrm{LH}$ level $>8.6 \mathrm{mIU} / \mathrm{mL}$ were considered Group 3 (high) (n = 57). Patients with a T level of $0-249 \mathrm{ng} / \mathrm{dL}$ were considered Group 1 (low) $(n=45)$, patients with a T level 249-836 ng/dL were considered Group 2 (normal) ( $\mathrm{n}=$ 333), and those with a T level > 836 ng/dL comprised Group 3 (high) ( $n=4)$. Upon classifying the patients into low, normal, and high hormone level groups, semen parameters were evaluated. Mean, standard deviation, and minimum and maximum values of volume, concentration, total motility, progressive motility, and morphology of semen were assessed according to FSH (Table 2), LH (Table 3), and $\mathrm{T}$ (Table 4) levels.

\section{Table 1.}

Mean data of patients. Results of hormone levels and sperm

characteristics of 382 patients included in the study. Minimum, maximum, mean, and standard deviation were determined for follicle-stimulating hormone (FSH), luteinizing hormone (LH), and testosterone (T) levels, and volume, total motility, progressive motility, concentration, and morphology.

\begin{tabular}{|lccccc|}
\hline & N & Minimum & Maximum & Mean & Std. Dev. \\
\hline FSH (mlU/mL) & 382 & 0.11 & 46.00 & 7.91 & 8.45 \\
\hline $\mathrm{LH}(\mathrm{mll} / \mathrm{mL})$ & 382 & 0.31 & 36.10 & 6.26 & 3.78 \\
\hline $\mathrm{T}(\mathrm{ng} / \mathrm{dL})$ & 382 & 1.94 & 1173.00 & 425.21 & 164.47 \\
\hline Volume $(\mathrm{mL})$ & 382 & 0.10 & 8.50 & 2.86 & 1.48 \\
\hline Total Motility (\%) & 382 & 0.00 & 90.00 & 41.90 & 26.39 \\
\hline Progressive Motility (\%) & 382 & 0.00 & 80.00 & 29.0393 & 21.79 \\
\hline Concentration (million/mL) & 382 & 0.00 & 190.00 & 26.40 & 33.60 \\
\hline Morphology (\%) & 382 & 0 & 10 & 1.79 & 1.95 \\
\hline
\end{tabular}

\section{Table 2.}

Values of semen parameters according to FSH level. Relationships between FSH levels and semen parameters. There was no statistically significant difference in semen parameters between the normal and low FSH groups $(p>0.05)$, but there was a significant difference in all semen parameters (with the exception of volume, $p=0.272, p>0.05$ ) between the normal and high FSH groups ( $p=0.000, p<0.05)$.

\begin{tabular}{|llccccc|}
\hline FSH group & $\begin{array}{c}\text { Volume } \\
(\mathbf{m L})\end{array}$ & $\begin{array}{c}\text { Concentration } \\
\text { (million/mL) }\end{array}$ & $\begin{array}{c}\text { Total } \\
\text { motility (\%) }\end{array}$ & $\begin{array}{c}\text { Progressive } \\
\text { motility (\%) }\end{array}$ & $\begin{array}{c}\text { Morphology } \\
(\%)\end{array}$ \\
\hline Low & Mean & 2.35 & 22.06 & 35.22 & 25.22 & 1.89 \\
& Std. Dev. & 1.47 & 22.58 & 28.99 & 24.4 & 1.83 \\
& Minimum & 0.20 & 0 & 0 & 0 & 0 \\
& Maximum & 5 & 67 & 75 & 65 & 4 \\
\hline Normal & Mean & 2.89 & 30.78 & 46.60 & 32.34 & 2.07 \\
& Std. Dev. & 1.48 & 34.72 & 23.39 & 20.45 & 1.97 \\
& Minimum & 0.10 & 0 & 0 & 0 & 0 \\
& Maximum & 8.50 & 190 & 85 & 75 & 10 \\
\hline High & Mean & 2.75 & 0.72 & 14.62 & 9.71 & 0.08 \\
& Std. Dev. & 1.48 & 1.99 & 26.74 & 19.25 & 0.38 \\
& Minimum & 0.30 & 0 & 0 & 0 & 0 \\
& Maximum & 7 & 11.50 & 90 & 80 & 2 \\
\hline
\end{tabular}

Table 3.

Values of semen parameters according to $\mathrm{LH}$ level. Relationships between $\mathrm{LH}$ levels and semen parameters. There was no statistically significant difference in any of the semen parameters between the normal and low $\mathrm{LH}$ groups ( $p>0.05)$, but there were significant differences in all semen parameters (with the exception of volume, $p=0.908, p>0.05$ ) between the normal and high LH groups ( $p=0.000, p<0.05)$.

\begin{tabular}{|lcccccc|}
\hline LH group & $\begin{array}{c}\text { Volume } \\
(\mathbf{m L})\end{array}$ & $\begin{array}{c}\text { Concentration } \\
\text { (million/mL) }\end{array}$ & $\begin{array}{c}\text { Total } \\
\text { motility (\%) }\end{array}$ & $\begin{array}{c}\text { Progressive } \\
\text { motility (\%) }\end{array}$ & $\begin{array}{c}\text { Morphology } \\
(\%)\end{array}$ \\
\hline Low & Mean & 2.05 & 4.30 & 30 & 15 & 1 \\
& Std. Dev. & 2.10 & 7.80 & 26.77 & 17.79 & 2 \\
& Minimum & 0 & 0 & 0 & 0 & 0 \\
& Maximum & 5 & 16 & 55 & 35 & 4 \\
\hline Normal & Mean & 2.88 & 30.05 & 44.80 & 31.22 & 2.03 \\
& Std. Dev. & 1.49 & 34.81 & 24.92 & 21.34 & 1.98 \\
& Minimum & 0.10 & 0 & 0 & 0 & 0 \\
& Maximum & 8.50 & 190 & 90 & 80 & 10 \\
\hline High & Mean & 2.80 & 7.43 & 26.40 & 17.71 & 0.49 \\
& Std. Dev. & 1.40 & 16.57 & 29.15 & 20.93 & 1.10 \\
& Minimum & 0.30 & 0 & 0 & 0 & 0 \\
& Maximum & 7 & 61 & 75 & 60 & 4 \\
\hline
\end{tabular}


Table 5.

Values of semen parameters according to $T$ level. Relationships between levels and semen parameters. There was no statistically significant difference in semen volume ( $p=0.069, p>0.05)$ or concentration $(p=0.063, p>0.05)$, but there was a strong statistically significant difference in total motility $(p=0.012, p<0.05)$ and progressive motility $(p=0.010, p<0.05)$, and a weak statistically significant difference in morphology ( $p=0.042, p<0.05$ ), between the normal and low T groups. There was no statistically significant difference in any semen parameter between the normal and high $T$ groups ( $p>0.05$ ).

\begin{tabular}{|llccccc|}
\hline T group & & $\begin{array}{c}\text { Volume } \\
(\mathbf{m L})\end{array}$ & $\begin{array}{c}\text { Concentration } \\
\text { (million/mL) }\end{array}$ & $\begin{array}{c}\text { Total } \\
\text { motility (\%) }\end{array}$ & $\begin{array}{c}\text { Progressive } \\
\text { motility (\%) }\end{array}$ & $\begin{array}{c}\text { Morphology } \\
(\%)\end{array}$ \\
\hline Low & Mean & 2.48 & 20.85 & 32.15 & 21.53 & 1.20 \\
& Std. Dev. & 1.52 & 31.12 & 28.22 & 21.38 & 1.50 \\
& Minimum & 0.20 & 0 & 0 & .00 & 0 \\
& Maximum & 6 & 130 & 85 & 75 & 6 \\
\hline Normal & Mean & 2.90 & 27.28 & 43.09 & 30.00 & 1.86 \\
& Std. Dev. & 1.47 & 34.03 & 26 & 21.74 & 1.99 \\
& Minimum & 0.10 & 0 & 0 & 0 & 0 \\
& Maximum & 8.50 & 190 & 90 & 80 & 10 \\
\hline High & Mean & 3.75 & 16.02 & 52.50 & 33.25 & 2 \\
& Std. Dev. & 1.25 & 17.00 & 15.54 & 17.95 & 2.30 \\
& Minimum & 2.00 & 2.40 & 30.00 & 8 & 0 \\
& Maximum & 5.00 & 40.00 & 65.00 & 50 & 4 \\
\hline
\end{tabular}

(2005) found significant correlations of FSH and inhibin B with semen parameters, but not with LH and T. Moreover, inhibin B level was not found to assist the diagnosis of infertility (20).

In our study, we investigated the statistical difference between normal and abnormal (low and high) hormone groups with semen parameters. We found no significant difference between the normal group and the low FSH/LH groups. However, we found significant differences in concentration, total motility, progressive motility and morphology between the high FSH/LH groups and the controls. There was a strong significant difference between the low and normal $\mathrm{T}$ groups with regard to total motility $(p=0.012$ ) and progressive motility $(\mathrm{p}=0.010)$, and a weak statistically significant difference in morphology $(p=0.042)$. However, we found no significant difference in semen volume and sperm concentration ( $\mathrm{p}>$ 0.05 ). There was no significant difference in any of the semen parameters between patients with high versus normal $\mathrm{T}$ levels ( $p$ > 0.05). In our study, we detected a sig-

\section{Discussion}

FSH is synthesized in the anterior lobe of the hypophysis gland and stimulates Sertoli cells to release inhibin B. LH is also synthetized in the anterior lobe of the hypophysis gland and increases intratesticular $\mathrm{T}$ levels by acting on Leydig cells. Intratesticular T stimulates the Sertoli cells in a paracrine manner and increases spermatogenesis. Previous studies have examined the effects of FSH, LH, and $\mathrm{T}$ levels on semen parameters. In a study by Kumanov et al. in 2006, FSH and LH levels were found to be significantly negatively correlated with semen parameters, while T levels were not correlated (14). The same study stated that inhibin B levels were a stronger indicator of infertility than FSH and LH levels (14). In a study by Subhan et al., serum hormone levels were compared between oligospermic and control groups. Serum LH and $\mathrm{T}$ levels were found to not be statistically different, but serum FSH levels were significantly higher in the oligospermic group compared to the control group (11). In a 2004 study of 1558 young Danish soldiers, Jensen et al. found significant correlations of FSH, LH and inhibin B with sperm concentration, motility and morphology (15). In another study in 2003, Uhler et al. reported significant correlations between FSH and inhibin B with concentration, motility and morphology. However, they found that LH and T levels did not correlate with those semen parameters (10).

Meeker et al. (2007) reported in their study significant negative correlations of FSH, LH with concentration, motility and morphology; however, T levels were significantly positively correlated only with motility (16).

In studies comparing the diagnostic value of inhibin $\mathrm{B}$ and FSH for infertility, inhibin B has been found to be superior by most $(9,14,17)$, although some favor FSH as a diagnostic marker of infertility $(18,19)$. Halder et al. nificant negative correlation between gonadotropin levels and semen parameters (with the exception of volume), a strong significant positive correlation between $\mathrm{T}$ levels and motility, a weakly significant correlation between $\mathrm{T}$ levels and morphology, and no correlations among semen volume, concentration, and T levels.

\section{Conclusions}

Many of these results are conflicting. The LH and T levels reported herein are not in agreement with the current literature. In most studies, although there was no association between semen parameters and $\mathrm{T}$ levels, our findings show a strong association between motility and $\mathrm{T}$ levels.

Because of the limited research that has been conducted on the relationship between $\mathrm{T}$ levels and sperm motility, there is a need for larger, randomized studies.

\section{References}

1. Greep RO. The dual nature of anterior pituitary influence on the testis. Anatomical Records 1937; 67 (Suppl.), 22.

2. Anderson RA, Sharpe RM. Regulation of inhibin production in the human male and its clinical applications. Int J Androl. 2000; 23:136-144

3. Anawalt BD, Bebb RA, Matsumoto AM, et al. Serum inhibin B levels reflect Sertoli cell function in normal men and men with testicular dysfunction. J Clin Endocrinol Metab. 1996; 81:3341-3345.

4. Sharlip ID, Jarow JP, Belker AM, et al. Best practice policies for male infertility. Fertil Steril. 2002; 77:873-882.

5. Behre HM, Yeung CH, Holstein AF, et al. Diagnosis of male infertility and hypogonadism. In Andrology 2001, Springer Berlin Heidelberg, pp.89-124. 
6. Mabeck LM, Jensen MS, Toft G, et al. Fecundability according to male serum inhibin B a prospective study among first pregnancy planners. Hum. Reprod. 2005; 20:2909-2915.

7. Jensen TK, Andersson AM, Hjollund NHI, et al. Inhibin B as a Serum Marker of Spermatogenesis: Correlation to Differences in Sperm Concentration and Follicle-Stimulating Hormone Levels. A Study of 349 Danish Men 1. JCEM. 1997; 82:4059-4063.

8. Pierik F, Burdorf A, De Jong F, Weber R. Inhibin B: a novel marker of spermatogenesis. Ann Med. 2003; 35:12-20.

9. Pierik FH, Vreeburg JT, Stijnen T, et al. Serum inhibin B as a marker of spermatogenesis. JCEM. 1998; 83:3110-3114.

10. Uhler ML, Zinaman MJ, Brown CC, Clegg ED. Relationship between sperm characteristics and hormonal parameters in normal couples. Fertil Steril. 2003; 79:1535-1542.

11. Subhan F, Tahir F, Ahmad R, Khan, Z. Oligospermia and its relation with hormonal profile. J Pak Med Assoc. 1995; 45:246-247.

12. Mahmoud AM, Comhaire FH, Depuydt CE. The clinical and biologic significance of serum inhibins in subfertile men. Reprod Toxicol. 1998; 12:591-599.

13. World Health Organization. WHO Laboratory Manual for the Examination and Processing of Human Semen. 5th edn. WHO, 2010.
14. Kumanov P, Nandipati K, Tomova A, Agarwal A. Inhibin B is a better marker of spermatogenesis than other hormones in the evaluation of male factor infertility. Fertil Steril. 2006; 86:332-338.

15. Jensen TK, Andersson AM, Jørgensen N, et al. Body mass index in relation to semen quality and reproductive hormonesamong 1,558 Danish men. Fertil Steril. 2004; 82:863-870.

16. Meeker JD, Bailey LG, Russ Hauser. Relationships between serum hormone levels and semen quality among men from an infertility clinic. J Androl. 2007; 28:397-406.

17. Brugo-Olmedo S, De Vincentiis S, et al. Serum inhibin B may be a reliable marker of the presence of testicular spermatozoa in patients with nonobstructive azoospermia. Fertil Steril. 2001; 76:1124-1129.

18. Bohring C, Krause W. Serum levels of inhibin B in men with different causes of spermatogenic failure. Andrologia, 1999; 31:137-141.

19. Andersson AM, Petersen JH, Jørgensen N, et al. Serum inhibin $B$ and follicle-stimulating hormone levels as tools in the evaluation of infertile men: significance of adequate reference values from proven fertile men. JCEM. 2004; 89:2873-2879.

20. Halder A, Fauzdar A, Kumar A. Serum inhibin B and folliclestimulating hormone levels as markers in the evaluation of azoospermic men: a comparison. Andrologia, 2005; 37:173-179.

\section{Correspondence}

Mehmet Zeynel Keskin, MD zeynel_akd@hotmail.com

Salih Budak, MD

Orçun Çelik, MD

Oguz Mertoglu, MD

Mehmet Yoldas, MD

Yusuf Özlem Ilbey, MD

Tepecik Research and Education Hospital, Clinic of Urology

Güney Mahallesi, 1140/1 Sokak, No:1 Yenişehir- Konak- İmir, Turkey

Tugba Zeyrek, MD

Tepecik Research and Education Hospital, Assisted Reproductive

Techniques Department, Clinic of Embryology, Izmir, Turkey 